\title{
What Role Do I Play in My Learning? A Study on the Academic Engagement of Higher- Education Students
}

\author{
Florencia Teresita Daura \\ Universidad Austral, Escuela de Educación; Centro Interdisciplinario \\ de Investigaciones en Psicología Matemática y Experimental-CIPPME. CONICET
}

Julio Cesar Durand

Universidad Austral, Escuela de Educación)

Abstract

The study of academic engagement has gained international visibility due to various factors operating in the social environment, such as fragmentation, 'liquidity' in interpersonal relations, etc., which end up affecting the persistence rates in studies, or its manifestation in an increasing rate of desertion in higher studies on the part of Argentine students. This research has been carried out within this framework, where 350 students of University and College education, who are enrolled in technical, humanistic-pedagogical and economic studies, completed the Academic Engagement Scale (Daura \& Durand, 2018) with the purpose of analyzing, on the one hand, their level of involvement with their studies; and on the other hand, inquiring on the existing connection with demographic variables.

Keywords: academic engagement, measuring devices, higher education.

\section{Introduction}

We live in a social context featured by fastness, superficiality, successfulness, seduction, instability, consumerism, the lack of a sense for which to live, and the questioning of ideas (Bauman, 2013)

Faced with this, in the educational field some thinkers, academics, researchers and pedagogues come up, as beacons lightning the road and acting as a gust of air that oxygenates, and they try to give light and provide solutions for improvement to what at first glance seems negative and even destructive.

Among the topics widening the horizon is the academic engagement, a meta-construct which investigation is introduced even with a certain paradox, if we take into account the above-mentioned environment and the meaning of the first term that makes it up. Admittedly, undertaking a commitment entails complying with the word given, being loyal and honest to oneself and to others, taking responsibility for the decisions made. At the same time, the engagement may be personal and collective and, in the school or academic path, it entails assuming a specific role; to this extent, it is colloquially said that a student or an institution are committed when they carry out the tasks concerning them.

To this extent, its study and analysis is valid if it is considered in connection with the serious problem of desertion. It is widely- known that the graduation rate of the Argentine university system is one of the lowest in the region and in the world; out of 100 students being admitted at the public education sector 74 do not graduate; while in the private sector, for the same number of students, 58 do not finish their studies. As regards the further education level, $55 \%$ of students who enroll at teacher training centers drop out in the first year of studies, and the graduation rate does not exceed $30 \%$ (Centro de Estudios de la Educación Argentina, 2018; Fernández, June $5^{\text {th }}, 2018$; Marcó del Pont, November $7^{\text {th }}, 2017$ ). Even those who are most critical of the educational and economic policies adopted last year say that more than 19,500 students dropped out of school in the 2017 academic year (Fdel, Jan, 31, 2018).

Within this framework, the present study is made, with the participation of 350 University and Further-Education-Level students who are taking technical, humanistic-pedagogical and economic studies in the province of Buenos Aires and in the Autonomous City of Buenos Aires (CABA), who completed the Academic Engagement Scale (Daura \& Durand, 2018) 
with the purpose of analyzing, on the one hand, their level of involvement with their studies; and on the other hand, investigating the existing connection with demographic variables.

To this end, firstly, after introducing a brief theoretical framework on the main study construct, in which such construct is defined and some of the research devices that were designed to evaluate it are described, the results achieved with the selected sample are discussed in detail.

\section{Theoretical Framework of Reference}

\section{What is the academic engagement?}

Involvement, responsibility, mission, agreement, treaty, are synonyms used to refer to the commitment. If we delve into its etymological root, it comes from the Latin term compromissum, which has two prefixes. The first, 'com', comes from the Greek koinos, which means common, joint; while the second, promissus, means promise. Thus, the term, in its affirmative and positive meaning, is "an undertaken obligation; [a] given word" (Real Academia Española, 2018, w.p.) it can also be considered as a joint promise made between two parties.

The commitment is also connected to the academic field, from the translation of the construct that in English is called academic engagement, which began to be studied in the Anglo-Saxon environment as a turn or change of focus on research regarding desertion and student retention.

Its meaning already states the interaction unfolding between two parties which are supposed to undertake a responsibility facing the decision making process and the resulting actions. In connection with the school or academic environment, the main characters in this interrelation are the learner and the educational institution, represented by the heads, teachers, tutors and other members of the institution.

It is precisely in this inter-play that one of the theoretical models used as a reference to explain the construct is anticipated. Specifically, the socio-cognitive theory, in which both the student and the educational organization are considered to have a leading role in the learning process and in the connection established between them.

Although there are many definitions of academic engagement, in this model it is understood as the process where the students and the teaching institution are involved, in which the former invest time and energy to carry out academic activities, and the latter strives to implement effective educational practices (Kuh, Cruce, Shoup \& Kinziey Gonyea, 2008). From this approach, the cognitive, affective-motivational and behavioral factors that intervene in the academic commitment are taken into account, which constitutes one of the most in-depth models for understanding the construct.

Fredericks, Blumenfeld and Paris (2004) specify the peculiarities of these three variables from the description of how they are seen in students (Table 1).

Table 1.

This model offers a very comprehensive vision of the construct, which allows us to approach it in an overall manner and to offer a better support to the student, as well as to the teachers or to each educational institution in order to promote it.

However, since it is a concept crossed by multiple variables that give a higher level of complexity to its approach, it is necessary to consider how to measure it in order to obtain the information necessary to assess it objectively.

\section{How to assess the academic engagement? Some instruments designed...}

Fredricks and McColskey (2012) and Veiga, Reeve, Wentzel \& Robu (2014) thoroughly describe the tools used to deepen the study of academic engagement. These include self-report scales, grading scales, interviews, and class observations. Although all of them offer advantages and disadvantages, generally speaking, Likert scales are the most frequently used because they allow us to obtain information that is not directly noticeable, and that refer to the students' perception of the object of study.

Many of the existing surveys explore the three variables recognized in the socio-cognitive model, while others focus on two or only one aspect. In addition, some surveys designed for the secondary education level are highlighted, such as the School Engagement Measure (SEM) (Fredricks, Blumenfeld, Friedel \& Paris, 2005). Others apply only at university and postgraduate levels: the Motivation and Engagement Scale (MES) (Lifelong Achievement Group, 2013), the Academic 
Involvement Questionnaire (QEA) (Abello Riquelme, Díaz Mujica, Pérez Villalobos, Almeida, Lagos Herrera, González Puentes \& Strickland, 2012), the Questionnaire of Academic Experiences (QVA) (Almeida, Ferreira \& Soares, 1999), the Survey of Well-being in an Academic Context (UWES-S) (Schaufeli \& Bakker, 2004).

At the same time, the importance given to the study of the construct had an impact on the implementation of programs aimed at obtaining unbiased information on the involvement of students in different countries, the results of which are used to make improvements in the education system. Within the context of these programs, the following research instruments were designed and are still being implemented: the National Survey of Student Engagement (NSSE) (Indiana University School of Education, 2016), which is applied in university institutions in the United States and Canada; the Australian Scale on Student Engagement (Australian Council for Educational Research, 2016, which is used in the southwestern region of Oceania; and the scales for undergraduate and graduate students in Great Britain and Northern Ireland (Higher Education Academy, 2015a; Higher Education Academy, 2015b).

\section{Methodology and Procedures}

\subsection{Sample}

A sample of 350 first-year college and university students was made.

An exploratory and descriptive investigation was carried out because the variables to be analyzed were observed as they happened in their natural context at a given moment.

\subsection{Purposes}

-Analyze the level of academic engagement of students in university and college education.

-Examine the existing connection between academic engagement and various socio-demographic variables, especially, gender, type of institution and type of studies.

\subsection{Instruments}

\section{Socio-demographic Questionnaire}

A questionnaire was designed to collect information regarding the gender, age, institution and studies of the subjects who took part in the study.

\section{Academic Engagement Scale}

It is an instrument designed and validated in previous studies (Daura \& Durand, 2018; Daura, in press) in accordance with the approaches of the socio-cognitive theory (Fredricks \& McColskey, 2012; Trowler, 2010); it has a Likert scale format and is made of 56 items, with five answer options ("0", which means "completely wrong", "1" "wrong", "2" "neither true nor wrong", "3" "true" and "4" "completely true").

The instrument is divided into three sections, which, in turn, are made of 13 variables that are defined and distributed as described in the following table (table 2).

Table 2

\subsection{Procedure}

The appropriate permission was requested from the authorities of the institutions taking part in the study; likewise, the students who completed the questionnaires were provided with information about the purposes of the work, the confidential and voluntary nature of their participation, and were given a document which they signed giving their consent.

The time taken to complete the instruments ranged from 40 to 60 minutes.

The scores of the Academic Engagement Scale were obtained by adding the subjects' choices and converting the figure to scale 10.

The data was processed using the program SPSS -Statistical Package for the Social Sciences - version 23.0. 


\section{Analysis of Results}

\subsection{Descriptive Statistics of the Academic Engagement Scale}

A descriptive analysis was made (minimum score, maximum score, population average and standard deviation) of the scores obtained by the students in the Academic Engagement Scale.

Table 3 shows the scores achieved in the Motivational Engagement section, among which the average of the variables Task Assessment and Intrinsic Motivation stand out, which would make them capable of assessing the contents and learning activities proposed by the institution, and of showing an interest in acquiring new knowledge.

At the same time, the students show a high level of anxiety, an effect that could be connected with the initial moment of the studies in which they currently are, a situation that usually generates uncertainty, and the need to adapt to a new, demanding and unknown environment.

\section{Table 3}

As for the descriptive statistics in the Cognitive Engagement section (table 4), the students stand out in the Organization variable, which would make them capable of selecting and organizing the important ideas of the contents learnt; and in the Extrinsic Regulation section, which would lead them to follow the guidelines and suggestions offered by the teachers, an issue connected both with the moment of their studies in which they currently are, where they would need to rely more on the experience of other people more skilled to guide their learning, as well as their autonomy and the achievement of good academic results. In fact, previous studies show how the students who are more adjusted and committed to their learning tend to rely more on their environment, to seek help from other people and to make all the necessary enquiries with sharpness and sagacity (Donolo; Chiecher, Paolini \& Rinaduo, 2008; Fernández Jacquez, 2015; Fredricks; Blumenfeld; Friedel \& Paris, 2005; Pintrich, Smith, García \& Mc Keachie, 1991; Zimmerman \& Schunk, 1989).

Table 4

As regards the descriptive statistics in the Contextual Engagement section (table 5), the average scores obtained in the variables, Positive Assessment of the Institution and Feelings of Belonging stand out, which show that students appreciate the actions carried out by the institution of which they are part of, in order to include them, which leads them to express greater interest in participating in the proposed activities and to feel part of it. These effects are linked to the "contextual model of academic engagement" of Lam, Wong, Yang and Liu (2012), in which it is argued that, as students increase their commitment to the institution, they develop more positive feelings towards it, towards the people with whom they interact (classmates, teachers, family members) and towards their own studying ability.

\section{Table 5}

In order to analyze to which extent the academic engagement can be explained by various socio-demographic aspects, subsequent analyses of variances (ANOVA one way) were made, in which, as dependent variables, the average scores reached by the sample in the variables of the Academic Engagement Scale were taken into account and, as an independent factor, gender, institutional level and type of studies were considered.

\subsection{Comparison of the sections of the Academic Engagement Scale according to gender}

Regarding the gender of the subjects who took part in the study, as a result of the variables analysis made, we notice that in the motivational section (Figure 1) significant differences were found for the women in the Task assessment ( $F=25,927$, $p<0,001)$ and Intrinsic motivation variables $(F=14,979, p<0,001)$; on the other hand, they scored less favorably on the anxiety variable $(F=3.168, p<0.076)$, which is close to statistically significant figures. These effects, in addition to agreeing with those reached in previous studies (Parada Contreras \& Pérez Villalobos, 2014; Parra \& Pérez, 2010; among others), respond to the unique profile of women, which is evidenced by greater responsibility, interest in the studies, dedication and effort to achieve academic goals and the involvement in the institutional context to which they belong. 
Figure 1.

In connection with the cognitive engagement section, women also outperform men in the Organization $(F=19,084, p<$ $0,001)$ and Time and Effort Management variables $(F=7,0469, p<0,008)$. In the Extrinsic Regulation variable, although differences close to statistical values were found, women also benefited (Figure 2).

These effects reinforce the results reported in the motivational engagement section, and evidence the ability of students to organize new knowledge, manage the time and effort needed to study, and the need to rely on instructions and suggestions from other experts (such as teachers) in order to implement learning activities. The latter may also be supported by the increased anxiety shown by women.

Figure 2.

Finally, in the Contextual Engagement section, women, compared to men, also achieved better scores in the Appreciation of the Institution ( $F=4.0189, p<0.046)$, Tutoring and Teaching $(F=15.062, p<0.001)$, and Feelings of Belonging variables $(F=3.6118, p<0.058)$, which could be an indication of how involved they are with the institution where they are studying (Figure 3).

Figure 3.

\subsection{Comparison of the sections of the Academic Engagement Scale in terms of the institution of belonging.}

The same analysis was made in order to confirm whether there are statistically significant differences in the scale of engagement based on the institution of belonging. To this extent, the sample was divided into two subgroups: University Level, made up of 225 students enrolled in university studies; and College Level, made up of 125 students enrolled in studies conducted by Teacher Training Institutes.

In the motivational engagement section (Figure 4) we noticed some interesting results that benefit college level students in the Task Assessment $(F=10,120, p<0,002)$ and Intrinsic Motivation variables $(F=11,833, p<0,001)$; and university level students in Extrinsic Motivation ( $F=18,443, p<0,001)$ and Anxiety variables $(F=4,523, p<0,001)$. These effects could indicate the presence of two types of motivational engagement profiles which, in the case of students undergoing college studies, could be deeper and could be evidenced by the appreciation of the contents and activities offered by teachers and tutors, as well as by the interest in acquiring new knowledge. On the other hand, in university students, the motivational engagement could be superficial, insofar as it would be directed towards acquiring new knowledge to satisfy external motivations, without worrying too much about the repercussions that this might have.

These results are consistent with other factors that are not analyzed here, such as, for example, the socio-economic level of the sample that took part in the study or the place of residence and proximity to the institution in which the studies are taken.

Figure 4.

In the cognitive engagement section (Figure 5), college students were favored in the use of Deep Strategies $(F=4.523, p$ $<0.034$ ); while university students had a greater command of Basic Strategies $(F=3,823, p<0,051)$, Extrinsic Regulation $(F=2,902, p<0,089)$ and Time and Effort Management $(F=4,676, p<0,031)$. These effects show that, while college students could have a greater ability to think reflexively and critically, make decisions, and accept the opinions of others, the performance of the commitment in this regard could be undermined by the failure to take advantage of the guidance provided by teachers or other experts, as well as by a reduced willingness to make the effort and organize the time needed to study; one might even think of these effects as a result of the influence of the institutional context, which in the case of these students offered less personal support.

Figure 5.

The last idea pointed out is based on the results obtained in the Institutional Engagement section (Figure 6) in which, although statistically significant differences were only reached in the Feelings of Belonging variable, in favor of university level students $(F=94,312, p<0,001)$, the scores obtained in Positive Assessment of the Institution and in Tutoring and teaching also benefitted this group of students. 
Figure 6.

\subsection{Comparison of the sections of the Academic Engagement Scale according to the type of studies.}

A new analysis of variances was made to confirm whether there are differences in the variables that make up the Academic Engagement Scale depending on the studies. For this purpose, the students sample was organized into three types of studies, in which case the supporting epistemic area was considered:

-Technical studies: 100 students enrolled in Industrial Engineering and Computer Engineering were recruited here.

-Humanistic-pedagogical studies: a group made up of 78 students who were enrolled in Psychology, bachelor studies in Psychopedagogy, History, Higher Education and Primary Education.

-Degrees in Economics: in which 111 students studied Bachelor of Business Administration, Bachelor of Agribusiness, Public Accountancy and Professorship in Economics.

In connection with motivational engagement, in the Task Assessment variable, the scores achieved benefit students who take Humanistic and Economic studies e $(F=5.538, p<0.004)(X=7.44$ and $X=7.45$, respectively). Likewise, Humanistic students also obtained the highest score in Intrinsic Motivation ( $F=8,001 p<0,001)$ and in Anxiety $(F=3,326, p<0,037)$; the latter effect does not benefit them and may be strongly influenced owing to the fact that the group is made up of a greater proportion of women.

Figure 7.

In the cognitive engagement section (graphic 8), students of humanistic programs outperformed others in the deep Strategies variables $(F=8,132, p<0,001)$; these same students, along with those of Economic Studies, also reached the highest score in the Organization variables $(F=7,924, p<0,001)$, proving to be more efficient in carrying out critical and reflexive reasoning, as well as incorporating new knowledge with the previously learned one.

Figure 8.

Finally, in the contextual engagement section (Figure 9), those who stated to have a greater connection with teachers and tutors are the students of Humanistic Studies, an effect which may be influenced by the fact of an affinity as regards the inherent duties of the future professional' role. $(F=4,912 p<0,008)$, or with the interest in learning from other people who are more expert. On the other hand, students of Technical Education were ahead of others in the Feelings of Belonging variable $(F=9,807, p<0,001)$.

Figure 9.

\section{Conclusion}

We believe that academic engagement implies the fulfillment of a promise made by two parties involved in the educational process: the student and the institution to which he or she belongs. The promise at issue concerns an academic goal that binds and connects these parties even closer, and that is related to starting and completing studies as successfully as possible. The scope of this goal implies challenges for both parties, which may be properly faced as long as dialogue and interaction are fluid and encourage mutual knowledge. On this basis, the study of academic engagement surpasses the approach of desertion and student retention, which concepts preceded it, and with which it shares some common questions, on the one hand, what are the reasons that influence students to drop their studies?, and on the other hand, what are the variables that encourage students to remain in the institution where they are studying?

We reassert that academic engagement has a unique focus in as much as it is based on interaction, on the participation that takes place between the student and the institutional parties, and is therefore process-based. It is not focused on identifying the consequences of the resulting failure - dropout of studies - or on the factors that help retaining the student, but on strengthening that relationship. This view makes the construct have an approach that, besides being preventive, is more customized; this idea supports, on one hand, the assertions made by Fredricks, Blumenfeld, Friedel and Paris (2005) regarding the existing relationship between academic engagement and self-regulated learning, and on the other hand, the assertion made in previous works on the "co-regulated customized spiral of learning" (Daura, 2013a, 2013b, 2017), a 
theoretical model which explains that at higher levels of support and advice provided by teachers, students improve the motivational and cognitive strategies they use in order to learn.

In accordance with these assumptions, this paper examines the results of a research conducted on 350 students of university and college education in Buenos Aires City and Buenos Aires Province, in order to measure their levels of academic engagement and connect these results with various socio-demographic variables. To this end, a questionnaire was administered in order to obtain information on gender, studies, and educational institution; as well as the Academic Engagement Scale (Daura and Durand, 2018).

As a result of the subsequent analysis, it was observed that the students who took part in the study, at the motivational engagement level, stand out for having a greater appreciation of the learning contents and the interest in grasping these contents. At the cognitive level, they stand out for organizing new knowledge and tending to follow the guidance offered by teachers; finally, at the contextual engagement level, for appreciating the institutions they are part of, and for having a feeling of belonging to them.

In this regard, the results obtained, although very positive, indicate the need to guide students so that they may develop a higher level of regulation of anxiety; and that they may make a greater use of deep thinking strategies as well as time management strategies to study. In addition, at the institutional level, tutorial strategies or academic counseling oriented to guide students' learning and favor their participation in the institution should be improved.

Connecting these results to demographic data shows that women have higher levels of motivational engagement; a greater cognitive engagement in the Organization, Extrinsic Regulation and Time and Effort Management variables; and a greater contextual engagement. These effects could be associated with previous studies on self-regulation and academic success, which evidence that women tend to show higher levels of performance (Meza Cano, de la Rosa Gómez, Rivera Baños \& González Santiago, 2018; Ndirangu, Muola, Kithuka \& Nassiuma, 2009; Suarez Riveiro, Ayana Nieto \& Gómez Veiga, 2016; Vrugt \& Oort, 2008; just to mention a few).

On the other hand, College students stand out for achieving better scores in all motivational variables; an effect that was reversed in cognitive variables, where they only reached the highest score in Deep Strategies and in contextual variables. Although it would be convenient to go deeper into the influence of age on these results, it is possible to assume that the higher levels of motivational engagement of students in college institutions will be associated with vocational variables. Indeed, the studies pursued by these students have a pedagogical orientation that is strongly related to both service and the desire to guide others to develop their full potential.

A similar result was observed when comparing the sections of the scale of academic engagement by type of studies, in which analysis the students of Humanistic Sciences were benefited both in motivational engagement and in two important variables of cognitive engagement, as well as in the Tutoring and Teaching variable in the contextual engagement section.

According to these results, it would be convenient, in future researches, to delve into the incidence of age in the development of academic engagement, on the existing differences between studies with pedagogical and humanistic orientation in connection with students' involvement. Likewise, it would be beneficial to compare these results with qualitative information obtained through interviews, focus groups, and life experiences, through which the subjectivity of the parties involved could be examined in greater depth.

\section{References}

[1] Abello Riquelme, R.; Díaz Mujica, A.; Pérez Villalobos, Ma. V.; Almeida, L. S.; Lagos Herrera, I.; González Puentes, J. y Strickland, B. (2012). Vivencias e implicación académica en estudiantes universitarios: adaptación y validación de escalas para su evaluación. Estudios Pedagógicos, 38(2), 7-19.

[2] Almeida, L.; Ferreira, J. y Soares, A. P. (1999). Questionário de vivências académicas (QVA e QVA-r). Minho, Portugal: Universidade do Minho \& Universidade de Coimbra.

[3] Australian Council for Educational Research (2016). Australasian Survey of Student Engagement (AUSSE), Camberwell. Australia. Consultado en http://www.acer.edu.au/ausse 
[4] Bauman, Z. (2013). Sobre la educación en un mundo líquido. Conversaciones con Ricardo Mazzeo. Buenos Aires: Ed. Paidós.

[5] Centro de Estudios de la Educación Argentina (2018). Nuestra graduación universitaria es escasa. Boletín del CEA. Universidad de Belgrano, 7(70), 1-14.

[6] Daura, F. T. (2013a). El contexto como factor del aprendizaje autorregulado en la educación superior. Educación y Educadores, 16(1)-, 109-125.

[7] Daura, F. T. (2013b). Incidencia de las estrategias didácticas personalizadas en el desarrollo del aprendizaje autorregulado en estudiantes universitarios. Una experiencia en la carrera de Medicina (Tesis de doctorado inédita). Facultad de Filosofía y Letras. Universidad Nacional de Cuyo, Argentina.

[8] Daura, F. T. (2017). Aprendizaje autorregulado e intervenciones docentes en la universidad. Revista Educación, 41(2), 2215-2644. Consultado en https://revistas.ucr.ac.cr/index.php/educacion/article/view/21396/pdf

[9] Daura, F.T. y Durand, J.C. (2018). ¿Cuán involucrado estoy? Un estudio exploratorio sobre el compromiso académico y la orientación temporal en estudiantes argentinos. Revista panamericana de pedagogía, 26, 7395. Consultado en http://portalderevistasdelaup.mx/revistapedagogia/index.php/pedagogia/article/view/283

[10] Daura, F. T. (en prensa). El compromiso académico y la experiencia subjetiva del tiempo en estudiantes de profesorados. Revista Contextos de Educación.

[11] Donolo, D.; Chiecher, A.; Paolini, P. y Rinaudo, M. C. (2008). MSLQe - MSLQvv. Motivated Strategies Learning Questionnaire. Propuestas para la medición de la motivación y el uso de estrategias de aprendizaje. Río Cuarto: EFUNARC. Universidad Nacional de Río Cuarto.

[12] Fdel, C. (31 de enero de 2018). Mas deserción universitaria. Consultado en https://www.pagina12.com.ar/92596-mas-desercion-universitaria.

[13] Fernández, M. (5 de junio de 2018). En las universidades públicas, el $74 \%$ no se recibe a tiempo y la mitad no aprueba más de una materia por año. Clarín. Consultado en https://www.infobae.com/educacion/2018/06/05/en-las-universidades-publicas-el-74-no-se-recibe-y-la-mitadno-aprueba-mas-de-una-materia-por-ano/

[14] Fernández Jacquez, L. F. (coord.) (2015). Autorregulación académica. Proceso desde la asociación de los estudiantes. Durango: Instituto Universitario Español. Consultado en http://www.redie.mx/librosyrevistas/libros/autorregulacion.pdf.

[15] Fredricks, J. A.; Blumenfeld, P.C. \& Paris (2004). School Engagement: Potential of the Concept, State of the Evidence. Review of Educational Research, 74(1), 59-109.

[16] Fredricks, J. A.; Blumenfeld, P. C.; Friedel, J. \& Paris, A. (2005). School engagement. In K. A. Moore \& L. Lippman (Eds.), Conceptualizing and measuring indicators of positive development: What do children need to flourish (pp. 305-321). New York, United States of America: Kluwer Academic/Plenum Press.

[17] Fredricks, J. A. \& McColskey, W. (2012). The Measurement of Student Engagement: A Comparative Analysis of Various Methods and Student Self-report Instruments. In: S. L. Christenson; A. L. Reschly \& C. Wylie (Eds), Handbook of research on student engagement (pp. 763-782). New York, United States of America: Springer.

[18] Higher Education Academy (2015a). Postgraduate Research Experience Survey PRES. Consultado en https://www.heacademy.ac.uk/research/surveys/postgraduate-research-experience-survey-pres

[19] Higher Education Academy (2015b). Using the National Student Survey (NSS) for enhancement. Consultado en http://www.heacademy.ac.uk/nss

[20] Indiana University School of Education (2016). About NSSE. Consultado en http://nsse.indiana.edu/html/about.cfm 
[21] Kuh, G., Cruce, T., Shoup, R., Kinzie, J. \& Gonyea, R. (2008). Unmasking the effects of student engagement on first year college grades and persistence. Journal of Higher Education, 79(5), 540-563.

[22] Lam, S.; Wong, B.; Yang, h.\& Liu, Y. (2012). Understanding student engagement with a contextual model. En S. Christenson; A. Reschly \& C. Wylie (Eds.), Handbook Research on Student Engagement (pp. 403-419). New York, United States of America: Springer.

[23] Lifelong Achievement Group (2013). The Motivation and Engagement Scale (MES). Consultado en http://www.lifelongachievement.com/the-motivation-and-engagement-scale-mes-i8/

[24] Marcó del Pont, T. (7 de noviembre de 2017). Sólo el 30\% de los estudiantes universitarios se recibe: cuál es el plan del Gobierno para revertir la baja graduación. Consultado en https://www.lanacion.com.ar/2079952-soloel-30-de-los-estudiantes-universitarios-se-recibe-cual-es-el-plan-del-gobierno-para-revertir-la-baja-graduacion

[25] Meza Cano, J. M.; de la Rosa Gómez, A.; Rivera Baños, J. y González Santiago, J. (2018). Evaluación de autorregulación académica en estudiantes de psicología en modalidad en línea. Voces de la educación, 3(6), $126-141$.

[26] Ndirangu, G.H.; Muola, J.M; Kithuka, M. R. \& Nassiuma, D. K. (2009). An investigation of the relationship between test anxiety and academic performance in secondary schools in Nyeri district, Kenya. Global Journal of Educational Research, 8 (1 y 2), 1-7.

[27] Parra P., P. y Pérez V., C. (2010). Propiedades psicométricas de la escala de compromiso académico, UWESS (versión abreviada), en estudiantes de psicología. Revista de Educación en Ciencias de la Salud, 7(2), 128133. Consultado en http://www2.udec.cl/ofem/recs/anteriores/vol722010/RECS7210.pdf\#page=26

[28] Parada Contreras, M. y Pérez Villalobos, C. E. (2014). Relación del engagement académico con características académicas y socioafectivas en estudiantes de Odontología. Revista de Educación Medica Superior, 28(2), 199-215. Consultado en http://scielo.sld.cu/pdf/ems/v28n2/ems03214.pdf

[29] Pintrich P., Smith D., García T. y Mc Keachie W. (1991). A manual for the use of the Motivated Strategies for Learning Questionnaire (MSLQ). Michigan: National Center for Research to Improve Postsecondary Teaching and Learning. University of Michigan.

[30] Real Academia Española (2018). Diccionario de la Real Academia Española. Consultado en http://dle.rae.es/?id=A41ilou

[31] Trowler, V. (2010). Student engagement literature review. York: The Higher Education Academy.

[32] Schaufeli, W. B. \& Bakker, A. B. (2004). Bevlogenheid: Een begrip gemeten. Work engagement: The measurement of a concept, Gedrag \& Organisatie, 17, 89-112. Consultado en http://www.wilmarschaufeli.nl/publications/Schaufeli/211.pdf

[33] Suarez Riveiro, J.M.; Anaya Nieto, D. y Gomez Veiga, I. (2004). Diferencias diagnosticas en función del género respecto a la utilización de estrategias autorreguladoras en estudiantes universitarios. Revista de Investigación Educativa, 22(1). 245-258.

[34] Veiga, F. H.; Reeve, J. M.; Wentzel, K. \& Robu, V. (2014). Assessing student's engagement: A review of instruments with psychometric qualities. Lisboa, Portugal: Instituto de Educação da Universidade de Lisboa. Consultado en http://repositorio.ul.pt/handle/10451/18036

[35] Vrugt, A. y Oort, F.J. (2008). Metacognition, achievement goals, study strategies and academic achievement: pathways to achievement. Metacognition and Learning, 3(2), 123-146.

[36] Zimmerman, B. y Schunk, D. (1989). Self-regulated learning and academic achievement: Theory, research and practice. New York: Springer-Verlag. 


\section{Tables}

Table 1.

Characteristics of the variables that make up the academic engagement

Variable
Behavioral Engagement

Manner in which it shows in students

Compliance with rules of co-existence established in the classroom and in the institution in general:

Paying attention, participation,

respectful acceptance of other people's ideas and

effort regulation

Academic engagement

Emotional engagement

Intrinsic motivation

Extrinsic motivation

Task appreciation

Anxiety regulation

Regulation of other negative emotions

Cognitive Engagement Thought elaboration

Meta-cognition

Critical or reflexive thinking

Organization

Source: own elaboration from Fredericks, Blumenfeld and Paris (2004)

Table 2. Description of the 13 extracted variables

Section 1. Motivational Engagement: made of 17 items, it studies four motivational affective components

Task Assessment It shows the usefulness, the importance and value given to the contents, and to the learning activities given in the institution.

Intrinsic Motivation

It shows the interest in learning the contents and/or bibliographic material suggested by the institution.

Extrinsic Motivation

It shows an interest in studying in order to satisfy external motivations (such as getting good grades, obtaining recognition from others), and to learn on the basis of the guide provided by the context

Anxiety It shows the anxiety felt in stressful situations of academic life, such as an examination.

Section 2. Cognitve Engagement: made of 27 items that study the cognitive strategies used to learn, by means of the following variables:

Deep Strategies

It shows the extent to which elaboration strategies are used and the extent to which prior knowledge is used in order to solve problems, make decisions, conduct critical assessments, and accept the opinions from others.

Basic Strategies

It shows the extent to which review strategies are used to learn to re-read class notes, memorize Keywords or concepts).

Organization

Extrinsic Regulation

It shows the ability to select and organize the important concepts of the studying material. It shows the strategies applied by the subject when adjusting to the indications made by the teacher.

Management of Time and It indicates both the personal willingness to strive for academic work, even when difficult, and the Effort ability to organize the time needed to study

Team Work It shows the willingness to work and learn as a team in the institutional environment.

Section 3. Contextual Engagement: made of 12 items that assess the actions the institution carries out in order to support the student and promote his/ her academic involvement, as well as the participation of the latter in the activities proposed by the institution and his/ her identification with the moral standards fostered by the educational institution. Such items are distributed in the following variables:

\begin{tabular}{|c|c|}
\hline $\begin{array}{l}\text { Positive Assessment of the } \\
\text { Institution }\end{array}$ & $\begin{array}{l}\text { It indicates the extent to which the student appreciates various actions that are carried out on the } \\
\text { part of the institution to promote different skills and encourage integration among students. }\end{array}$ \\
\hline Teaching and Tutorship & $\begin{array}{l}\text { It shows the extent to which the actions carried out by tutors and teachers are appreciated in order } \\
\text { to facilitate students' learning and encourage their participation in the institution. }\end{array}$ \\
\hline Feelings of belonging & $\begin{array}{l}\text { It assesses the feelings of belonging that the student has and that are promoted by the institution } \\
\text { by means of various academic activities. }\end{array}$ \\
\hline
\end{tabular}

Source: Daura and Durand (2018) 
Table 3

Description of the Motivational Engagement section

\begin{tabular}{|c|c|c|c|c|c|}
\hline Variables of the Motivational Engagement section & Students & Minimum Score & Maximum Score & Average & DS \\
\hline Assessment of the task & 150 & 2,81 & 10,00 & 7,40 & 1,42 \\
\hline Intrinsic Motivation & 150 & 1,88 & 10,00 & 6,92 & 1,81 \\
\hline Extrinsic Motivation & 150 & 0,00 & 10,00 & 6,05 & 2,00 \\
\hline Anxiety & 150 & 0,00 & 10,00 & 5,03 & 2,18 \\
\hline
\end{tabular}

Source: own compilation

Table 4

Description of the Cognitive Engagement section

\begin{tabular}{|c|c|c|c|c|c|}
\hline Variables of the Cognitive Engagement section & Students & $\begin{array}{l}\text { Minimum } \\
\text { Score }\end{array}$ & Maximum Score & Average & DS \\
\hline Deep Strategies & 150 & 1,25 & 10,00 & 6,25 & 1,54 \\
\hline Basic Strategies & 150 & 0,00 & 10,00 & 4,41 & 2,31 \\
\hline Organization & 150 & 0,63 & 10,00 & 7,20 & 1,80 \\
\hline Extrinsic Regulation & 150 & 0,00 & 10,00 & 6,59 & 1,69 \\
\hline Management of time and effort & 150 & 0,50 & 10,00 & 5,73 & 1,86 \\
\hline Team work & 150 & 0,83 & 10,00 & 6,10 & 1,74 \\
\hline
\end{tabular}

Source: own compilation

Table 5

Description of the Contextual Engagement section

\begin{tabular}{llllll}
\hline Variables of the Contextual Engagement section & Students & Minimum Score & Maximum Score & Average & DS \\
\hline Positive Assessment of the Institution & 150 & 1,25 & 10,00 & 6,98 & 1,74 \\
Teaching and Tutorship & 150 & 0,00 & 10,00 & 4,57 & 2,18 \\
Feelings of belonging & 150 & 0,63 & 10,00 & 5,42 & 1,70 \\
\hline
\end{tabular}

Source: own compilation.

\section{Figures}

Figure 1.

Differences between men and women in the motivational section of the Academic Engagement Scale

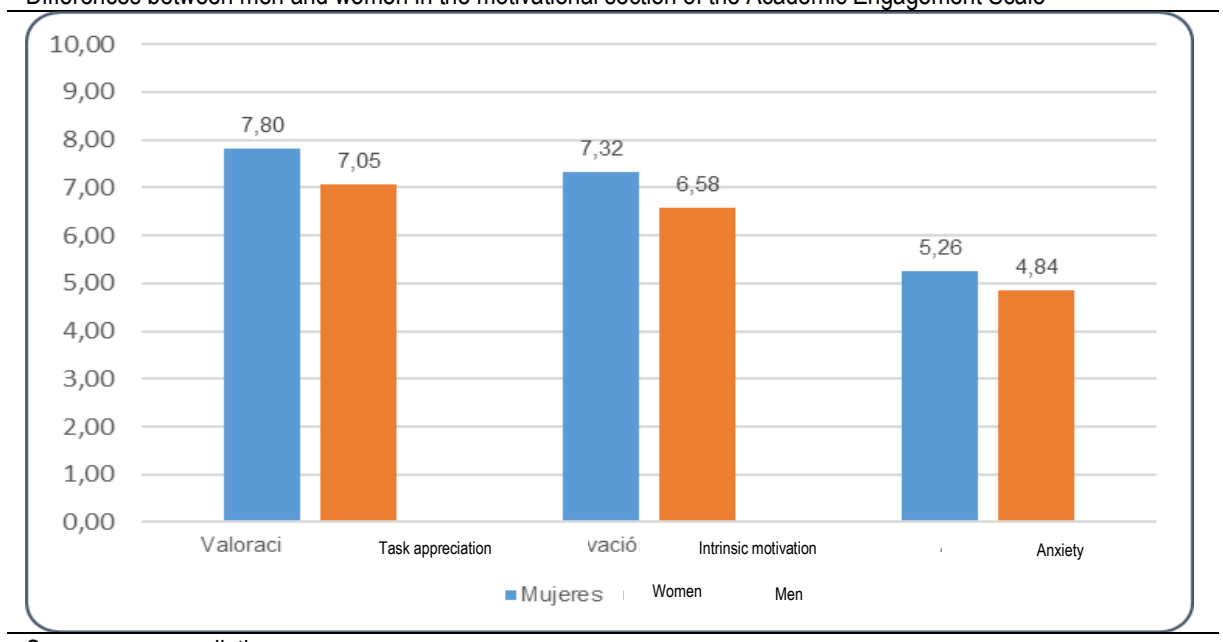

Source: own compilation 
Figure 2.

Differences between men and women in the cognitive engagement section of the Academic Engagement Scale

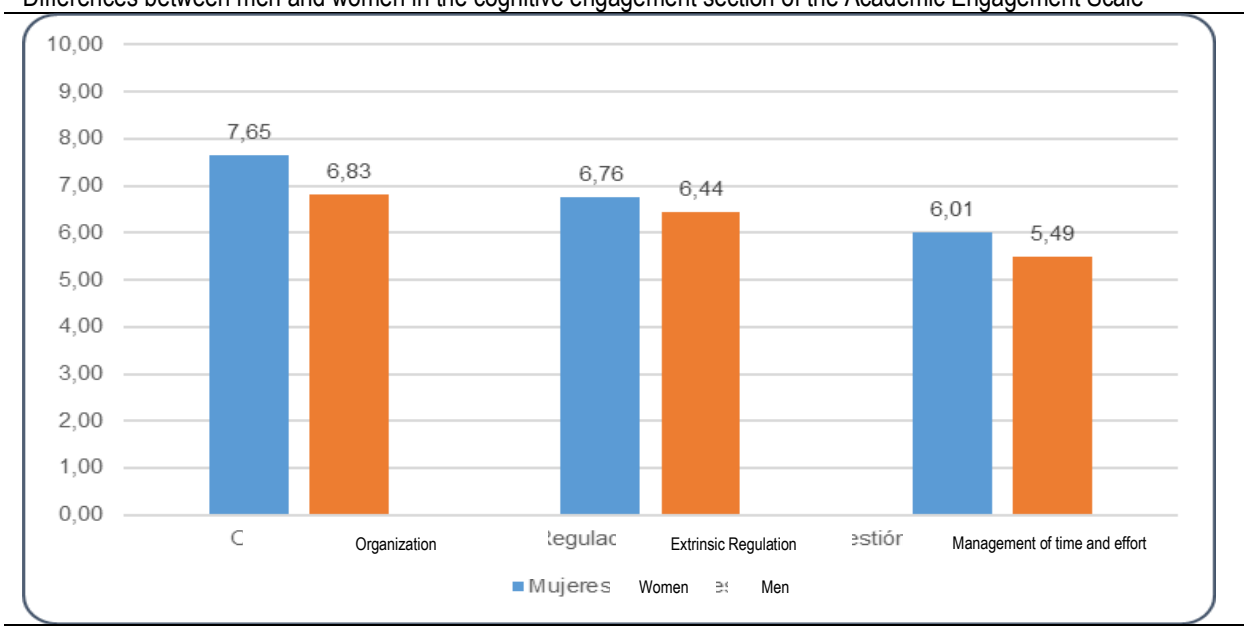

Source: own compilation

Figure 3.

Differences between men and women in the contextual engagement section of the Academic Engagement Scale.

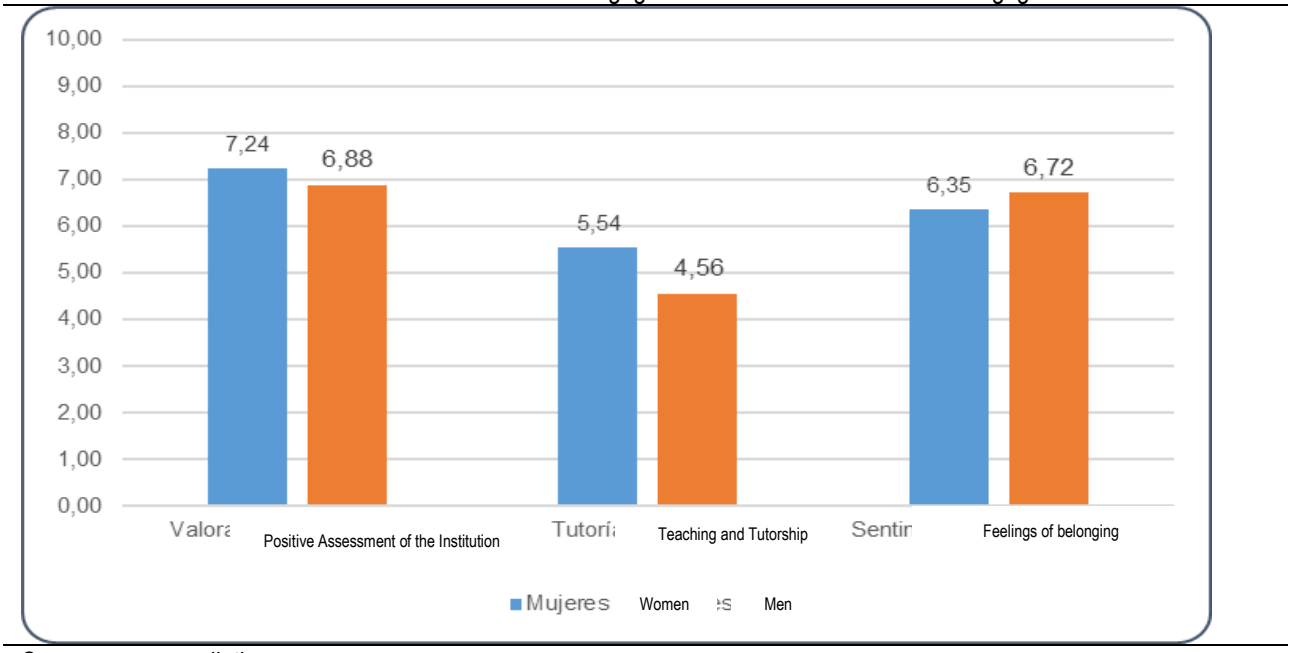

Source: own compilation 
Figure 4.

Differences between university and college students in the motivational engagement section of the Academic Engagement Scale.

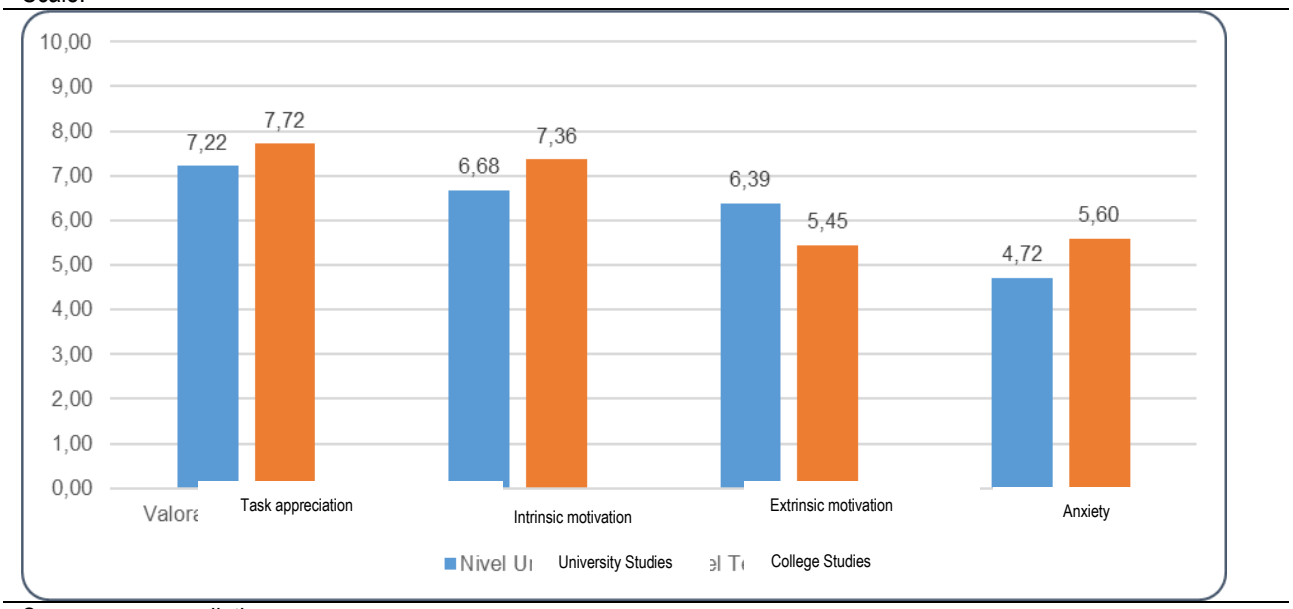

Source: own compilation

Figure 5.

Differences between university and college students in the cognitive engagement section of the Academic Engagement Scale.

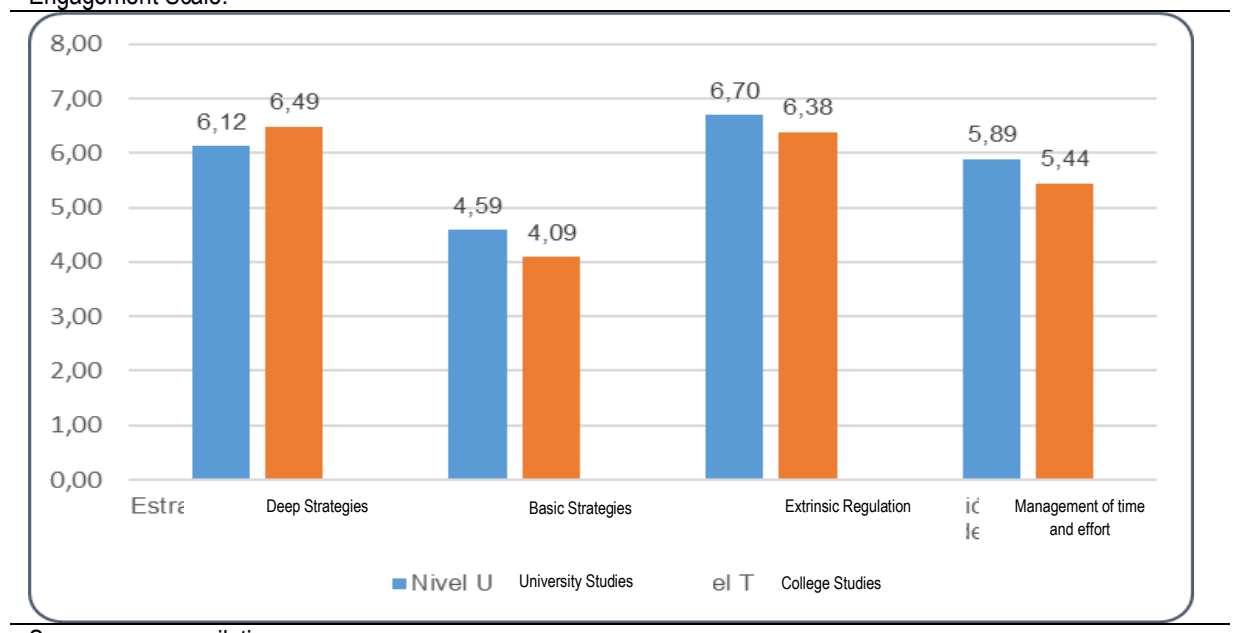

Source: own compilation 
Figure 6.

Differences between university and college students in the contextual engagement section of the Academic Engagement Scale.

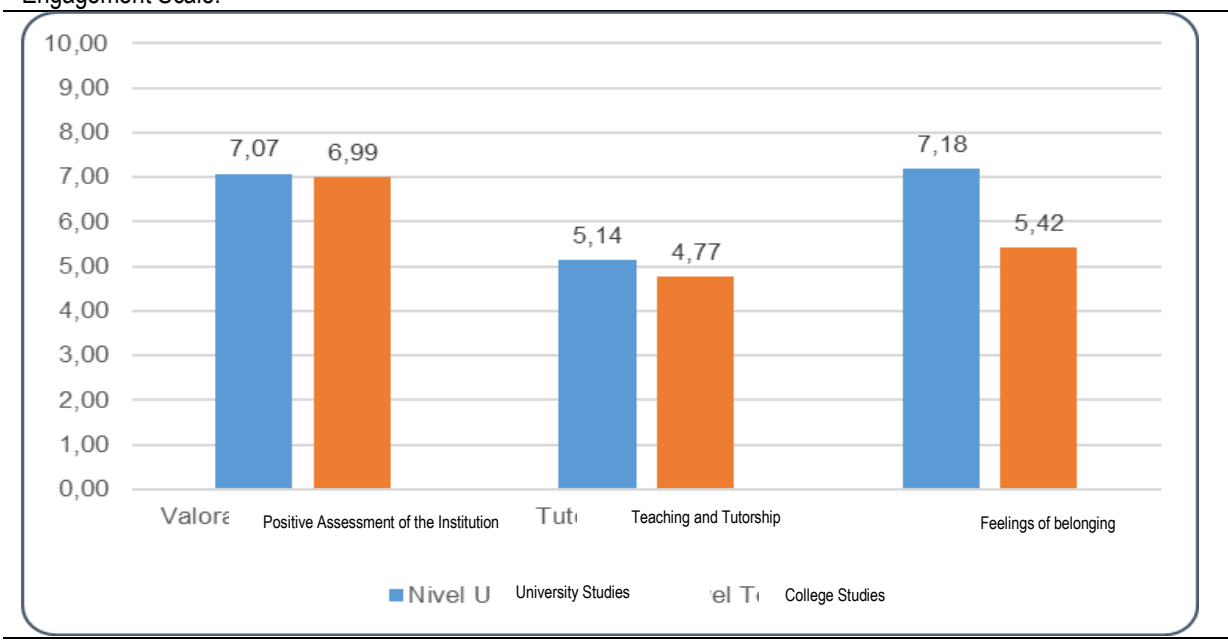

Source: own compilation

Figure 7.

Differences according to the type of studies in the motivational engagement section of the Academic Engagement Scale

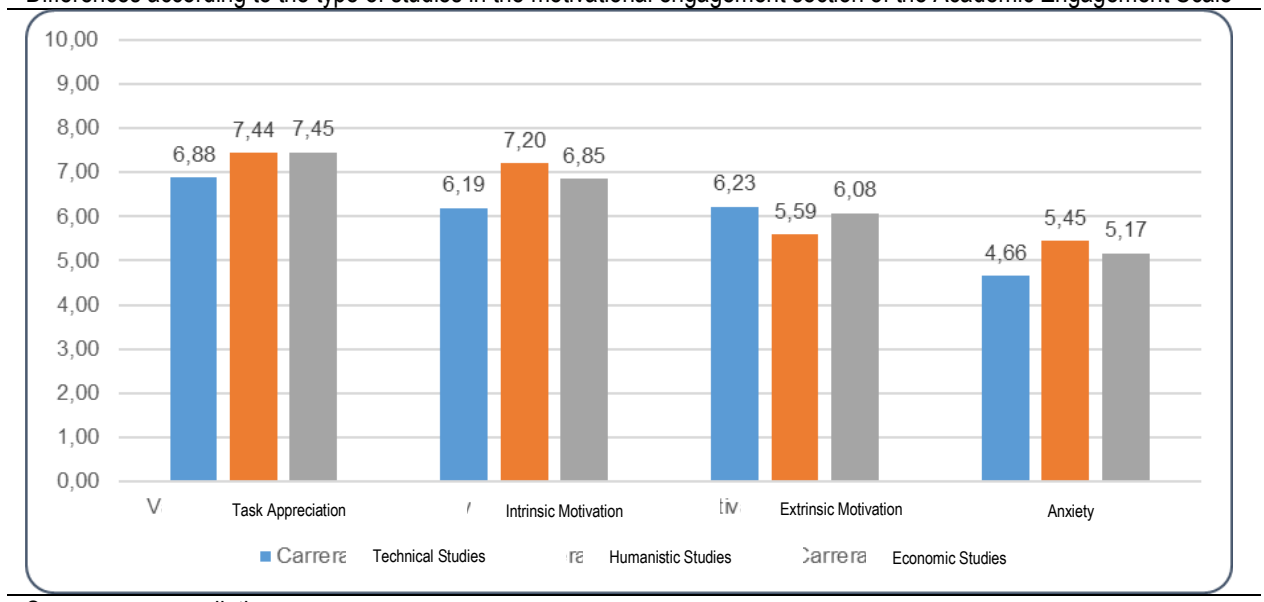

Source: own compilation 
Figure 8.

Differences according to the type of studies in the cognitive engagement section of the Academic Engagement Scale

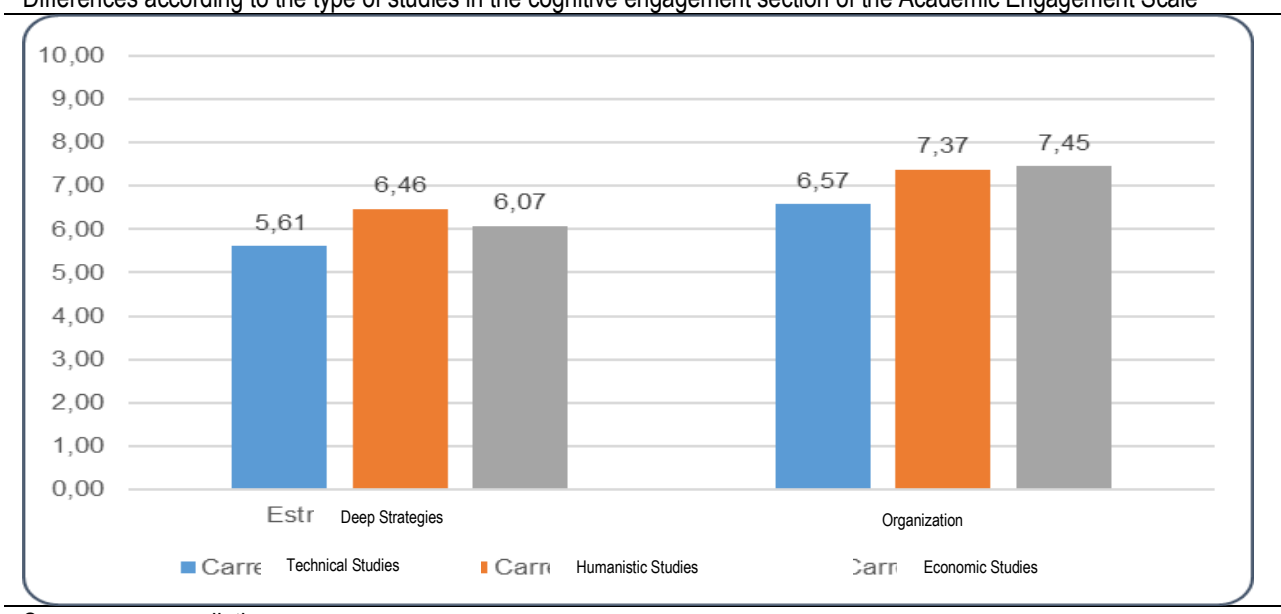

Source: own compilation

Figure 9.

Differences according to the type of studies in the contextual engagement section of the Academic Engagement Scale

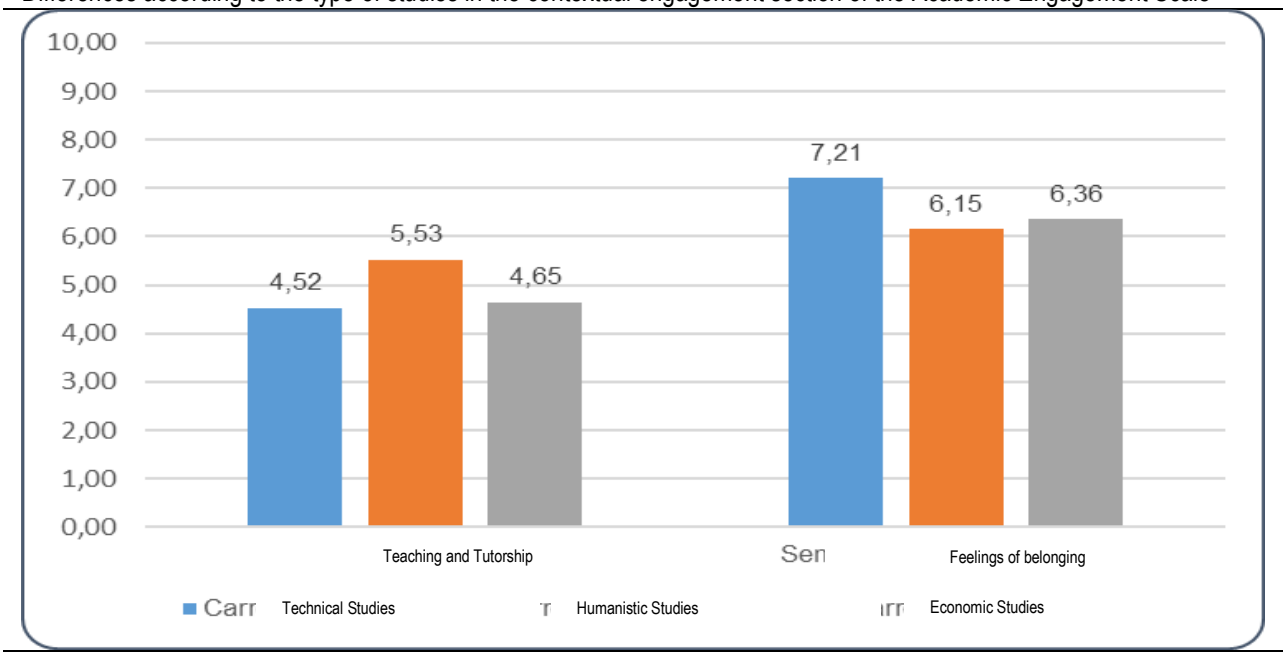

Source: own compilation 